Wilfrid Laurier University

Scholars Commons @ Laurier

Ancient Studies

Faculty of Arts

1988

The Beginning of Greek Polychrome Painting

Gerald Schaus

Wilfrid Laurier University, gschaus@wlu.ca

Follow this and additional works at: https://scholars.wlu.ca/ams_faculty

Recommended Citation

Schaus, Gerald, "The Beginning of Greek Polychrome Painting" (1988). Ancient Studies. 6.

https://scholars.wlu.ca/ams_faculty/6

This Article is brought to you for free and open access by the Faculty of Arts at Scholars Commons @ Laurier. It has been accepted for inclusion in Ancient Studies by an authorized administrator of Scholars Commons @ Laurier. For more information, please contact scholarscommons@wlu.ca. 


\title{
THE BEGINNING OF GREEK POLYCHROME PAINTING
}

\author{
(Plates III-IV)
}

Авоuт the mid-seventh century, polychrome styles of vase painting appeared in five different Greek wares, and in a sixth ware a short time after. ${ }^{1}$ By polychrome here is meant the use of a light brown or reddish brown paint for male flesh in human figure scenes, to go with the normal colours found on seventh-century Greek vases, black, red and white. The use of this light brown or reddish brown paint may have begun a little earlier, e.g. for parts of animals, but it would be confusing to call this partial polychrome and to regard this as a preliminary step towards the distinctive use of brown for male human flesh. ${ }^{2}$ The six wares in which polychrome vases appear are Protocorinthian, ${ }^{3}$ Protoattic, ${ }^{4}$ Argive, ${ }^{5}$ Naxian, ${ }^{6}$ 'Melian' (likely from Paros), ${ }^{7}$ and a ware found at Megara Hyblaea. ${ }^{8}$ Except for 'Melian' polychrome which continues to the end of the seventh or early sixth century, each of these polychrome styles flourishes for a brief time and then disappears. ${ }^{9}$

Protocorinthian is the best dated of these wares. Payne noted that the polychrome vases from Corinth all grouped around the work of a single artist (Macmillan [Chigi] Painter) or small circle of artists whose most famous vase, the Chigi olpe PLATE III(a), is normally dated ca. 640 BC. ${ }^{10}$ The earliest vases, aryballoi in Berlin and the Louvre, were put about the mid century by Payne. ${ }^{11} \mathrm{~A}$ date in the decade before $650 \mathrm{BC}$ may be acceptable for the beginning of Protocorinthian polychrome vases (advanced MPC or MPC II).

This paper was first delivered as a lecture at the American School of Classical Studies in February, 1987. I wish to thank G. L. Huxley and Martin Robertson who read earlier drafts of this paper, and also A. Baker and the other members of a seminar on East Greek painting I offered at the American School in winter, 1987 for their helpful criticisms.

${ }^{1}$ By mid-seventh century I take to mean the decade before and after 650 вС. The origin and development of the polychrome style in these wares was discussed recently by F. Villard, $A S A A$ n.s. xliii I (I98I) I 33-8.

${ }^{2}$ Villard (n. I) divided the early use of polychrome decoration into four phases. The first phase he called 'polychromie partielle', dated after ca. 670 BC. This included the occasional use of brown on animals and objects. Its use in this way may have begun before its use for male flesh; however, when found on animals or objects it is arbitrarily applied and is not clearly related to its regular use for male flesh. For examples of Protocorinthian vases with this brown (sometimes described as yellow) on animals, see H. Payne, Necrocorinthia (Oxford I93 I) II n. 3.

${ }^{3}$ K. F. Johansen, Les vases sicyoniens (Paris, Copenhagen 1923) 97-9, 103-4, I I3; Payne (n. 2) 94-7; J. L. Benson, Die Geschichte der korinthischen Vasen (Basel 1953) I6-19, 68, 70 ('Painter of the Berlin Centauromachy', 'Ekphantos Painter'); A. Newhall Stillwell-J. L. Benson, Corinth XV, iii (Princeton 1984) nos. 275, 285, 288, 30I, 304; see also D. A. Amyx -P. Lawrence, Corinth VII, ii (Princeton I975) I $2-\mathrm{I} 3$ no. I.

${ }^{4}$ K. Küblë̈, Altattische Malerei (Tübingen 1950) I 8 I9; id., Kerameikos vi, 2 (Berlin 1970) I, I47-8, 453, 456-66. See also p. 108 and $n$. I 3 below.

${ }^{5}$ P. Courbin, $B C H$ lxxix (I955) I-49 pl. I.

${ }^{6}$ F. Salviat-M. Weill, $B C H$ lxxxiv (I960) 347-86 pls. IV-VI; Ch. Karusos, JdI lii (1937) I 66-97. For other fragments, see Praktika I960, pl. I96a (note pl. 197a,c);
Praktika I96I, pl. I 56c; $A S A A$ n.s. xlv 3 (1983) i 7 figs. 2I-2; likely also Délos xvii, I7 no. B4.2 I9 pls. 9.2, 70 .

7 D. Papastamos, Melische Amphoren (Münster I970) dating summary p. I 35 ; and most recently Ph. Zapheiropoulou, Problemata tes meliakes aggeiographias (Athens I985) 79-90, Ior-7 dating summary p. I5s. For a lower dating of 'Melian' polychrome, see below n. I9. Clay analysis suggests a home for 'Melian' pottery on Paros, see R. E. Jones et al., Greek and Cypriot pottery (Athens I986) 652-8.

8 G. Vallet-F. Villard, Mégara Hyblaea ii (Paris I964) I63-72, I92; F. Villard, $A S A A$ n.s. xliii I (I98 I) I34-7; also G. Vallet, F. Villard, P. Auberson, Mégara Hyblaea iii (Rome I983) I 56 figs. 65-9. The use of brown for male flesh on these vases begins about the mid-seventh century.

${ }^{9}$ Five of the six wares were dated by R. M. Cook to about the mid-seventh century (Greek painted potter ${ }^{2}$ [London 1972] pp. 5I, 71, 92, II 2, I46). 'Melian' polychrome began a bit later, perhaps two decades after the beginning of non-polychrome 'Melian', which is dated ca. 650 by Cook, p. I I 4 . Later polychrome vases appear also in Thasian, Cretan, Samian, East Dorian, Cycladic and Chian wares, all before the mid-sixth century.

10 Payne (n. 2) I 8, 94-7; T. J. Dunbabin-M. Robertson, BSA xlviii (I953) I79-80 (Macmillan Painter).

11 Payne (n. 2) 94; id., Protokorinthische Vasenmalerei (Berlin I933) I 3-I 4 (caption to pl. 2 I). Benson (n. 3) I6, 68-9 attributed the aryballos in Berlin to the Painter of the Berlin Centauromachy and put it in his Early Protocorinthian III group apparently dated to the 670's. Dunbabin-Robertson, BSA xlviii (I953) I79, however, called this vase a very early work of the Macmillan Painter. A date in the 650s seems most likely. 
A number of polychrome vases, made especially for funerary use, were found in the Kerameikos cemetery in Athens. They were dated to the 650 os on the basis of the grave sequence. ${ }^{12}$ Polychrome sherds from the Athenian agora (PLATE III $[b]$ ) are very close in style to the polychrome Argive krater, but they may, in fact, be Attic as Villard believed. ${ }^{13}$

On the basis of figure style as well as comparisons of technique with Protocorinthian, the lone polychrome vase from Argos, PLATE III $(c)$, depicting the Blinding of Polyphemos, was dated to a little before the mid-seventh century. ${ }^{14}$

The well known Bellerophon plate from Thasos, PLATE III $(d)$, was given a mid-seventh century date by its first publishers, though some wish to place it a little earlier, ca. 660 BC. ${ }^{15}$ The Aphrodite amphora from Naxos, Plate $\operatorname{IV}(a)$, should be dated about the same time. ${ }^{16}$

'Melian' has been the subject of two recent studies. ${ }^{17}$ In both, the authors opted for a high chronology for the 'Melian' series, putting the earliest of the great amphoras ca. $670 / 660 \mathrm{BC}$. Papastamos, however, dates the first polychrome amphora ca. $640 \mathrm{BC}$, while Zapheiropoulou suggests $670 / 660$ for the first polychrome. ${ }^{18}$ The difficulty with this high chronology is that the latest 'Melian' vases must belong to the late seventh or early sixth century $\mathrm{BC}$, as both Zapheiropoulou and Papastamos realize, but there is hardly a sufficient stylistic development from earliest to latest vases to support so long a period of production as they propose. Rather the filling ornaments on the earliest 'Melian' style vases compare well with those on vases of the late Black and White style of Protoattic pottery. This would suggest a date around the mid-seventh or later for the beginning of 'Melian', as Cook and Boardman have noted. ${ }^{19}$ The Apollo amphora PLATE IV $(b)$, therefore, seems to fit better $c a$. $630 \mathrm{BC}$, certainly not before $c a$. 640, about 30 years later than the date suggested by Zapheiropoulou.

Polychrome vases from Sicily (PLATE IV $[c]$ ) show some influences from Protocorinthianfor example, in the use of incision. There is little evidence for sustained development of the style in the few vases which are preserved. Though Villard, arguing from the figure style, would put the earliest pieces using brown paint ('polychromie partielle' and perhaps 'polychromie totale') into the second quarter of the seventh century, there seems no reason to think that these vases are in advance of mainland Greek work. ${ }^{20}$ Again the mid century for the introduction of brown for male flesh is a good estimate.

Almost without exception the vases decorated in the polychrome style are among the finest products of seventh-century vase workshops. The scenes are complex human-figure ones, either taken from myth or depicting complicated battle scenes of a generic sort. The vases from the Kerameikos were for funerary purposes; their themes reflect these uses.

It has occasionally been suggested that the development of polychrome vase painting was in fact independent of 'free' painting. ${ }^{21}$ This view, however, may be coloured by the exigencies of preservation; 'free' paintings are rarely preserved as opposed to vase paintings. Although 'free' and vase painters were in close touch, there is no reason to suppose a dependence of 'free' painters on those artists painting vases, and certainly no reason for two independent developments of the polychrome style.

The more common view is that the polychrome technique in vase painting owes a debt to

12 Kübler, Kerameikos vi, 2, p. I ('Anlage XI').

13 Hesperia ii (I933) 572-3 no. I33 figs. $3 \mathrm{I}-2$; E. Brann, Agora viii (Princeton I962) ros nos. 649-5I pl. 4I. See F. Villard, $A S A A$ n.s. xliii I (I98I) I 34.

$14 \mathrm{P}$. Courbin, $B C H$ lxxix (I955) $32-5$.

15 F. Salviat-N. Weill, BCH lxxxiv (I960) 382-6. Mer Égée, Grèce des îles (Paris 1979) no. 59 p. I I 7-18. F. Villard, $A S A A$ n.s. xliii I (I98I) I $33-4$ puts it in his partial polychrome phase.

16 Ch. Karusos, JdI lii (1937) I 87-95 suggested a date in the middle of the second quarter. This was supported by J. K. Brock, $B S A$ liv (1949) 76-80, who, however, believed the Aphrodite amphora and the 'Melian'
Apollo amphora were about contemporary. Yet the Apollo amphora should date after the mid-century, see n. I9 below.

17 Papastamos (n. 7); Zapheiropoulou (n. 7).

18 For references, see n. 7.

19 J. Boardman, BSA xlvii (I952) 24, 26; id., Island gems (London I963) 90, I05-6; Cook (n. 9) IO5, I I 4.

20 F. Villard, $A S A A$ n.s. xliii I (I98I) I $33-5$.

21 For example, F. Villard, $A S A A$ n.s. xliii I (I98I) I37. I prefer the term 'free' painting to 'monumental' or 'mural' painting, following D. A. Amyx in W. G. Moon, ed., Ancient Greek art and iconography (Madison I983) 37-8. 
'free' painting, that is, that it was from the stimulus of 'free' painting that vase painters attempted to imitate the more varied colour scheme. Certainly the few examples of 'free' painting we have from the Archaic period - the Thermon metopes, Pitsa plaques, plaque from the Acropolisuse the wider palette including a brown or reddish brown for male flesh. Polychrome painting was the norm in Egyptian 'free' painting. It seems most economical to suppose that this same polychrome style came directly into Greek 'free' painting, rather than through Greek vase painting first. ${ }^{22}$

Two polychrome vases, the Chigi olpe Plate III $(a)$ and the Argive krater fragment Plate $\mathrm{III}(c)$, were noted by M. Robertson, as being especially influenced by 'free' painting. ${ }^{23}$ Not only are they in the polychrome style, with the convention of brown painted male flesh common to Egyptian painting, but there is an irregular disposition of the figures on both vases, and some indication of landscape (rocks in the Polyphemos scene; bushes for the hunting scene on the Chigi vase). The feeling of depth produced by the massing and considerable overlapping of figures in the Chigi vase battle scene may also be due to influence from 'free' painting.

It is worth remarking that East Greek wares were not affected by the sudden popularity of the polychrome style. The Wild Goat style had only recently taken hold in East Greece; its themes concentrated almost entirely on animal friezes and groups. Vase painters here were not drawn to the depiction of human figures, and so, it seems, were not interested in imitating the art of 'free' painting. They were content to decorate their vases with animals only and to leave human figures to other arts. It is, however, worth noting that two of the earliest human figured scenes on East Greek vases ( $c a .600 \mathrm{BC}$ ) are in the polychrome style, i.e. on the Euphorbos plate from the East Dorian area, and on a hydria from Samos. ${ }^{24}$ This style is also found on Chian pottery in the second quarter to mid-sixth century, not long after the start of more complex human figure scenes on Chian chalices. ${ }^{25}$

Polychrome style vases in six different fabrics appear about the mid-seventh century or shortly after, and at least two of these vases seem to reflect the art of 'free' painting through their composition. Villard explains this phenomenon by suggesting that transient vase painters spread the style. He does this because there is little evidence that the vases themselves were exported. ${ }^{26}$ There are, however, too few other similarities between the wares to support this idea. It seems more likely that it was the art of 'free' painting in polychromy which gave rise to this development. Because of the sudden appearance of polychrome vases in so many fabrics, it is reasonable to suppose that there was just at this time a new development in 'free' painting which spread quickly through Greece, perhaps through its appearance at panhellenic sanctuaries. A novel development in a major art form given prominent expression in Greek places of gathering and worship might readily explain exactly the kind of imitation seen in the mid-seventh century art of vase painting.

In support of this there are the fragments of wall painting from the early Archaic temples at Corinth and Isthmia. The seventh-century temple of Apollo at Corinth is preserved only in the debris of its destruction. It was dated by its excavator to $c a .700$ BC. $^{27}$ Further consideration of the pottery associated with its construction, and comparisons with the Temple of Poseidon at Isthmia suggest that the temple must be later than $c a$. $680 \mathrm{BC}$, though earlier than the Poseidon temple. ${ }^{28}$ It may tentatively then be dated to the second quarter of the century. The interior

\footnotetext{
22 For the relationship between vase painters and 'free' painters see, M. Robertson, 'The place of vasepainting in Greek art', $B S A$ xlvi (I95I) i 5 I-9.

${ }^{23}$ M. Robertson, Greek painting (Geneva I959) 437.

24 Euphorbos plate, E. Simon, Die griechischen Vasen (Munich 1976) 54-5 no. 3 I; R. M. Cook, BABesch lviii (1983) 2-3. Samos hydria, A. E. Furtwängler, AthMitt XCv (I980) I 88-97 figs. 8-I I pls. $54-5$ beil. I.

25 For the style, see E. R. Price, JHS xliv (1924) 2 I $7^{-}$ г9; J. Boardman, $B S A$ li (1956) 59-60.

26 F. Villard, $A S A A$ n.s. xliii I (I98I) I 37. Protocor-
}

inthian is certainly exported, but its style is quite different from most of the other polychrome wares.

27 H. S. Robinson, 'Temple Hill, Corinth', in U. Jantzen, ed., Neue Forschungen in griechischen Heiligtümern (Tübingen 1976) 239-50, especially p. 246 (dating); id., Hesperia xlv (I976) 2 I I-I 2 (dating), 224-35.

${ }_{28}$ J. B. Salmon, Wealthy Corinth (Oxford I 984) 60; $\mathrm{R}$. Rhodes, The beginnings of monumental architecture in the Corinthia (Dissertation, University of North Carolina, Chapel Hill I984) ro4-8. I am grateful to Ch. Williams for these references and discussion on the dating of this temple. 
walls of this temple were plastered and painted in what might have been panels either solid black in colour or solid red, with a thin reserved border. One fragment preserves what looks like a ray from a decorative border. ${ }^{29}$ There is no indication of figured scenes, though one fragment of a terracotta plaque, suggested to be decoration from the interior of the temple, may have a tree with bare branches painted dark brown against a light brown background. ${ }^{30}$ Since it is unclear what relation this fragment had to the early temple, it is best to leave it aside. The wall paintings give no hint of polychrome painting such as is seen on the Temple of Poseidon at Isthmia.

According to recent study of the Isthmia temple, this building was probably constructed no earlier than the middle of the seventh century. Fragments of wall painting have been found on blocks of the temple, but their disposition on the building is still not resolved. ${ }^{31}$ The pieces are too fragmentary to allow a close dating though one large piece with a horse's neck (PLATE IV [d] top) shows that the mane was depicted in a manner common to the second and third quarters of the seventh century. Large locks of hair rise in waves above the neck and are divided into three strands by two curving lines. Another fragment (PLATE IV $[d]$ bottom) has a diagonal meander used as a border which like the representation of the mane can be paralleled on the Bellerophon plate from Thasos (PLATE III $[d]$ ) of the mid-seventh century. ${ }^{32}$ This temple was located right at the isthmus, a major thoroughfare for land traffic and terminus for sea traffic. It later became the site of one of the four panhellenic games. Since nearby Corinth and Sikyon claimed the position of inventor of painting among the Greeks, according to Pliny, it may well be that the Isthmian sanctuary helped spread the new polychrome style of painting.

Pliny, our fullest source for the development of Greek painting, twice mentions Egypt as the originator of painting (N.H. vii 205 , xxxv I6). He clearly suggests that from there the idea came to Greece (in Graeciam transiret) although he goes on to mention 'inventors' in Greece. Robertson and Boardman, among others, have noted the role which Egypt probably played in the spread of 'free' painting in colour to Greece. ${ }^{33}$ The appearance of polychrome vases around the midseventh century coincides exactly with our historical sources which describe the opening up of Egypt to Greeks. ${ }^{34} \mathrm{We}$ are told by Herodotus that the pharaoh Psammetichos used Ionians and Carians as mercenaries to establish his position among the kings of Lower Egypt. ${ }^{35}$ Assyrian records also mention that the same Psammetichos was sent armed forces by Gyges, probably Greek and Carian mercenaries, to help drive the Assyrians from Egypt. ${ }^{36}$ Since Psammetichos established his position in Lower Egypt by ca. 660 and the mercenaries sent by Gyges must have arrived before 652, the date of Gyges' death, it is clear that large numbers of Greeks for the first time were allowed to live in Egypt just before the middle of the century. The wonders of the ancient land were there for all the Greek visitors to see and to learn from. The art of monumental stone sculpture was likely one result of the new contact with Egypt. ${ }^{37}$ Some borrowing in the area of stone architecture, particularly its technical aspects, may also be traced. ${ }^{38}$ It is not, I think,

29 Robinson, Hesperia xlv (1976) 228 pl. 5 I.

30 Ibid., pl. 5 Ib right (C-7I-285).

31 For the paintings, see O. Broneer, Isthmia I, The temple of Poseidon (Princeton 197I) 33-4 figs. 53-4 pls. A-C. On the date of the temple, see R. Rhodes (n. 28) I04-8, I $35-6$ who suggests that the paintings were on the interior of the temple. The variety of colours used at Isthmia is greater than on contemporary polychrome vase painting, including purple and light blue.

32 Bellerophon plate, F. Salviat-N. Weill, $B C H$ lxxxiv (I960) pl. VI. Salmon (n. 28) 60 suggested a midseventh century date for the wall paintings on stylistic grounds.

${ }^{33}$ Robertson (n. 23) 43-6, 75; J. Boardman, The Greeks overseas $^{3}$ (London 1980 ) $147-53$.

${ }^{34}$ For a good historical account, see $C A H^{2}$ III, iii, $35-7$.

35 Hdt. ii I47, I5I-54; see also Diod. Sic. i 66.I2.
Diodorus (i 66.7-9) also mentions Greek merchants trading with Psammetichos' region of Egypt. If true, this could not have occurred much if at all before the hiring of Greek mercenaries by Psammetichos.

${ }^{36}$ Rassam cylinder, D. D. Luckenbill, Ancient records of Assyria and Babylonia ii (Chicago 1927) nos. 784-5. The events are discussed by $\mathrm{H}$. Kaletsch, Historia vii (1958) 27-9 who dates the help sent Psammetichos by Gyges to ca. 655 BC.

37 See Boardman, Greeks overseas ${ }^{3}$ (n. 33) I44.

38 Ibid., I43. For the Greek debt to Egyptian architecture especially in technical matters, see J. J. Coulton, Greek architects at work (London 1977) 32-50, and p. 49-50 regarding the significance of dating the Corinth and Isthmia temples for the argument of Egyptian influence. On a lower dating for these two temples, to the mid-seventh century, Salmon (n. 28) 60. 
coincidental that the complex process of making faience appears on the island of Rhodes at this very time $^{39}$ The earliest faience vases are surprisingly similar to the objects made in Egypt, but because of the complexity of the process, V. Webb suggested that Egyptians or Phoenicians rather than Greeks started the workshops on Rhodes. ${ }^{40}$ In any case the techniques of this craft appeared in Greece in the mid-seventh century, giving one some justification for supposing that a similar transfer of technical knowledge occurred at this time in the art of 'free' painting. ${ }^{41}$

From the archaeological evidence of vase painting and wall painting it appears that polychrome painting became popular in the years shortly before $650 \mathrm{BC}$, perhaps begining $\mathrm{ca}$. $660-655$ BC.

The opening up of Egypt to Greeks, from all the evidence available, was a product of the initiative of East Greeks, but there is little evidence to show that it was East Greeks who brought the new artistic influences back home from Egypt. Stone sculpture appears first in the islands; architecture is harder to trace though Crete and the mainland were early recipients of ideas; faience-making, however, was established in East Greece, and for the moment there are only circumstantial reasons against Greeks being the actual manufacturers. ${ }^{42}$ In painting, the evidence from polychrome vases, if not conclusive, certainly does not support an East Greek priority. Pliny, who gives the most detailed description of the origins of Greek painting, states that some credited Corinth, others Sikyon with the invention. ${ }^{43}$ His source of information, however, was Xenokrates of Athens, a writer of the third century $\mathrm{BC}$ who may have been influenced by his own training as well as the importance of the Sikyonian school of painting by his own day. ${ }^{44}$

The evidence is not all against East Greece. Saurias of Samos is mentioned by Athenagoras as the first to discover shadow drawing, and Boularchos, presumably an East Greek, did the first painting whose subject matter we know, a battle or destruction of the Magnesians. ${ }^{45}$ The painting by Boularchos has caused scholars great difficulties. If such a painting did exist, and there is no immediate reason to reject Pliny's witness to it, then there is a problem in fixing its date since its theme suggests a date in the mid-seventh century, while its purchaser was said to be King Kandaules of Lydia who died about the 680's. The issue needs another look.

Pliny in two places in his Naturalis Historia sketches the early development of Greek painting. The passages follow: 46

39 V. Webb, Archaic Greek faience (Warminster 1978) 5 .

40 Ibid., 9-10. For other posited Phoenician workshops on Rhodes, producing unguent flasks, perhaps scarabs and other luxury items, see G. Markoe, Phoenician bronze and silver bowls from Cyprus and the Mediterranean (Berkeley, Los Angeles i985) i 27.

41 R. R. Holloway, $A J A$ xc (I986) 486 doubts such a transfer.

42 Above nn. 37-8 for influences on sculpture and architecture, and n. 40 for the nationality of early faience makers in Greece.

43 Plin. N.H. xxxv i $5-16$. It is a matter of speculation who Philokles of Egypt was, mentioned as the inventor of linear drawing by Pliny (N.H. xxxv I6). His name is Greek and it is possible he received his surname 'the Egyptian' from a trip or a stay he had in Egypt. See J.-M. Croisille, Pline l'Ancien, Histoire Naturelle, Livre $x x x v$, Texte établi, traduit et commenté, ed. Budé (Paris I985) I 40 n. I commentary to Plin. N.H. xxxv I6. For the evidence of Greek knowledge of Egypt before Psammetichos' reign, see M. M. Austin, Greece and Egypt in the Archaic age, PCPhS, supp. ii (1970) I I-I4.

${ }_{44}$ For references to discussions of Pliny's sources, see Croisille (above n. 43) is for Plin. N.H. xxxv i 5-i6, and pp. I7-1 8 for Plin. N.H. xxxv ss-6; for Xenokrates, see B. Schweitzer, Xenokrates von Athens (Halle
1932); E. Pernice in U. Hausmann, ed., Allgemeine Grundlagen der Archäologie, Handbuch der Archäologie (Munich I969) 494-6; A. Rumpf, RE ix B2 (1967) s.v. Xenokrates $^{\text {IO }}$ I53 I f.; and for a summary of work on Xenokrates, see R. Schoder in K. Jex-Blake and E. Sellers, The Elder Pliny's chapters on the history of art, first American ed. (Chicago I 968) p. 'G'. Sellers, p. xx n. 2 noted the strong Sikyonian slant to Xenokrates' writing, and so called him Xenokrates of Sikyon.

45 For Saurias, see Athenagoras, Presbeia peri Christianon, I7; and for Boularchos, Plin. N.H. xxxv 55, vi I 26 ('destruction' [exitium] of the Magnesians).

46 De picturae initiis incerta nec instituti operis quaestio est. Aegyptii sex milibus annorum aput ipsos inventam priusquam in Graeciam transiret adfirmant vana praedicatione, ut palam est, Graeci autem alii Sicyone alii aput Corinthios repertam, omnes umbra hominis lineis circumducta, itaque primam talem, secundam singulis coloribus et monochromaton dictam postquam operosior inventa erat, duratque talis etiam nunc. inventam liniarem a Philocle Aegyptio vel Cleanthe Corinthio primi exercuere Aridices Corinthius et Telephanes Sicyonius, sine ullo etiamnum hi colore, iam tamen spargentes linias intus. ideo et quos pingerent adscribere institutum. primus invenit eas colore testae, ut ferunt, tritae Ecphantus Corinthus.

Quid quod in confesso perinde est Bularchi pictoris 
The origin of painting is obscure, and hardly falls within the scope of this work. The claim of the Egyptians to have discovered the art six thousand years before it reached Greece is obviously an idle boast, while among the Greeks some say that it was first discovered at Sikyon, others at Corinth. All, however, agree that painting began with the outlining of a man's shadow; this was the first stage, in the second a single colour was employed, and after the discovery of more elaborate methods this style, which is still in vogue, received the name of monochrome.

The invention of linear drawing is attributed to Philokles of Egypt, or to Kleanthes of Corinth. The first to practise it were Arideikes of Corinth, and Telephanes of Sikyon, who still used no colour, though they had begun to give the inner markings, and from this went on to add the names of the personages they painted. The invention of painting with colour made, it is said, from powdered potsherds, is due to Ekphantos of Corinth.

\section{N.H. $\mathrm{xxxv}$ i $5-16$}

Again, is it not an undisputed fact that a picture of the battle ${ }^{47}$ of the Magnetes by the painter Boularchos was bought by Kandaules, also called Myrsilos, the last Lydian king of the line of the Heraklids, for its weight in gold, a proof of the honour already paid to painting? This must have taken place in the days of Romulus, for Kandaules died in the eighteenth Olympiad [708-705 BC], or, according to some authorities, in the same year as Romulus, and already then, unless I am mistaken, the art had attained to greatness, even to perfection. And if we must accept this, it follows that its first origin is much older, and that the early painters in monochrome, whose dates have not been handed down to us, lived some time before. Such, for example, were Hygiainon, Deinias, Charmadas, Eumaros of Athens, who was the first to mark the difference between man and woman in painting, and who ventured to imitate every sort of figure, and Kimon of Kleonai, who developed the inventions of Eumaros. He devised 'catagrapha', or profile drawings, and represented the features in different postures, looking backwards or upwards or downwards. He marked the attachments of the limbs, gave prominence to the veins, and also discovered the wrinkles and windings of drapery. Furthermore Panainos the brother of Pheidias painted the battle between the Athenians and Persians at Marathon. So extensively were colours now used, so perfect had technique now become...

N.H. $\mathrm{xxxv} 55-56$

(trans. K. Jex-Blake)

These two passages are generally regarded as being from the same source, Xenokrates, with the exception of the anecdote about Boularchos' painting, taken from Varro. ${ }^{48}$ It is difficult to say how Xenokrates compiled his information about the early development of painting. Perhaps he relied on an oral tradition which was supported by the remains of early paintings. In any case, the development of vase painting generally corroborates the accuracy of Pliny's brief history of painting, as will be seen. The story about Boularchos' painting is a 'hapax'. It could be mere legend, but because there is a certain ring of historical truth to it, it cannot be dismissed without good reason.

The two passages are complementary, with the second passage giving added information about the early stages of painting and then relating the later stages of the development of the art down to the fifth century BC. In these passages Pliny gives only one explicit indication of date for

tabulam, in qua erat Magnetum proelium, a Candaule rege Lydiae Heraclidarum novissimo, qui et Myrsilus vocitatus est, repensam auro? tanta iam dignatio picturae erat. circa Romuli id aetatem acciderit necesse est, etenim duodevicensima olympiade interiit Candaules aut, ut quidam tradunt, eodem anno quo Romulus, nisi fallor, manifesta iam tunc claritate artis, adeo absolutione. quod si recipi necesse est, simul apparet multo vetustiora principia eosque qui monochromatis pinxerint, quorum aetas non traditur, aliquanto ante fuisse, Hygiaenontem, Dinian, Charmadan et qui primus in pictura marem a femina discreverit, Eumarum Atheniensem figuras omnes imitari ausum, quique inventa eius excoluerit Cimonem Cleonaeum. hic catagrapha invenit, hoc est obliquas imagines, et varie formare voltus, respicientes suspicientesve vel despi- cientes. articulis membra distinxit, venas protulit, praeterque in vestibus rugas et sinus invenit. Panaenus quidem frater Phidiae etiam proelium Atheniensium adversus Persas apud Marathona factum pinxit. adeo iam colorum usus increbruerat adeoque ars perfecta erat...

47 Jex-Blake N.H. xxxv $55-56$

47 Jex-Blake translates proelium here as 'defeat' because of Pliny's other reference to the theme of this painting, N.H. vii I26: cf. below, p. I Is.

48 Croisille (n. 43) is, i 8 . See also above, n. 44. The Boularchos anecdote was apparently inserted where Pliny supposed it to belong in the relative development of painting. For Varro as its likely source, see F. Münzer, Hermes xxx (I 895) 54I-2; Croisille (n. 43) I7-I 8. 
his development of early painting; that is, that Boularchos' painting of the battle of the Magnesians was bought by the Lydian king, Kandaules. ${ }^{49} \mathrm{He}$ then adds that the origin of painting must be much earlier than this (multo vetustiora). Relying on earlier authors, Pliny errs in his date for Kandaules, believing his death to have occurred in the eighteenth Olympiad (708-705 BC). Adjusted lower for what we now know of Lydian regnal chronology-death of Kandaules ca. $685^{-680 ~ B C},{ }^{50}$ - the painting by Boularchos cannot have been painted any later than ca. $685 \mathrm{BC}$. The origin of painting (presumably in polychrome), therefore, must be placed much earlier than this, and the monochrome painters even earlier still. This, however, conflicts with other indications of date in Pliny. It also conflicts with the theme of Boularchos' painting and what we know of the development of 'free' painting from its sister art, vase painting.

The date of Kandaules is at variance with a second suggestion of date in Pliny. This second date, however, was rejected by Pliny because he erroneously accepted an early date for the development of painting in Italy. At N.H. xxxv I6-17, Pliny attributes the invention of painting in colour to Ekphantos of Corinth, yet he notes immediately that this painter, Ekphantos, is not the same Ekphantos, apparently also a painter, who, according to Cornelius Nepos, accompanied Demaratos of Corinth to Etruria sometime after the overthrow of the Bacchiads in 657 BC. The reason Pliny gives for his belief that there were two different people with the same name, home city and, it seems, occupation, is that Ekphantos was the inventor of painting with colour; yet the Italian tradition was that painting had already reached 'high perfection' (iam enim absoluta erat pictura etiam in Italia) before Demaratos and his group arrived. Pliny, however, realized that Italian painting could not be in advance of the Greek inventor of painting. ${ }^{51}$ The Italian tradition was certainly wrong. The paintings in Italy which Pliny believed to go back to the time of Romulus and earlier (N.H. xxxv I7-18) could not be any earlier than Demaratos, and probably no earlier than the sixth century. ${ }^{52}$ The coincidence between Ekphantos, the inventor of painting in colour, and Ekphantos, companion of Demaratos after 657 BC, is therefore striking. As Furtwängler suggested, there may in fact have been only one Ekphantos, and so we may have here a quite different suggestion of date for the beginning of Greek polychrome painting, a little before the mid-seventh century. ${ }^{53}$ If it was indeed Ekphantos, the inventor of painting, who accompanied Demaratos to Italy, then the year of the Bacchiad overthrow, $657 \mathrm{BC}$, would not necessarily represent the terminus ante quem for the invention of painting. Demaratos need not have left the very year of the overthrow, but it is likely he left Corinth within a few years of it since according to tradition he married in Etruria and had a son who became king of Rome by 6 I6 6 BC. $^{54}$ Though not impossible, it is hardly likely that Ekphantos 'invented' painting at least 30 years before the Bacchiad overthrow (but more probably 40 years or more, since Pliny says painting must have been invented much earlier [multo vetustiora] than the painting by Boularchos bought by Kandaules), and then left Corinth as an old man with Demaratos.

There is a little more evidence which supports a date close to the time of the Bacchiad overthrow for the introduction of polychrome painting to Greece. Pliny (N.H. vii 205) notes that the Egyptians invented painting and that according to Aristotle (Rose, fr. 382), Eucheir invented it or brought it to Greece. Perhaps not coincidentally there was a Eucheir who also

49 The lack of dates is due to Pliny's source, Xenokrates, see Schweitzer (n. 44) i 7.

50 Since Gyges' death must be lowered to about 652 BC from Herodotus' date ca. 68 I вC (i.e. I 35 years before the fall of Sardis ca. $546-$ Hdt. i is, I6, 25, 86), it is not certain how many years should be given to Gyges' reign. Herodotus was obviously mistaken about the length of reign of the other Lydian kings. For a date $c a$. $68 \mathrm{O} \mathrm{BC}$ for the beginning of Gyges' reign, see $\mathrm{H}$. Kaletsch, Historia vii (1958) 30-4.
51 Note A. Reinach, Recueil Milliet (Paris I92 I) $65 \mathrm{n}$. 9; Sellers (n. 44) 86 commentary to Plin. N.H. xxxv I6 lines 3 and 5; A. Furtwängler, Plinius und seine Quellen (Leipzig I 877) 25-6.

52 See Croisille (n. 43) I4 I n. I commentary to Plin. N.H. xxxv I7.

53 Furtwängler (n. 5I) 27.

54 For Demaratos as an historical entity, see A. Blakeway, JRS xxv (I935) I47-9. 
accompanied Demaratos to Etruria. ${ }^{55} \mathrm{He}$ is described as a clay modeller, but it is possible he was a painter of architectural terracottas. ${ }^{56}$

There is another method of arriving at a date for the various stages in Pliny's development of Greek painting; that is, by a comparison with the development of Greek vase painting. The key points in Pliny's two passages (above) outlining the development of Greek painting can be summarized as follows:

Plin. N.H. $\mathrm{xxxv}$ i5-16

Inventors: Egyptians, then among Greeks, Corinth or Sikyon

Stages:

I. Outlining of man's shadow

2. Single colour ('monochrome')

3. Linear drawing - inventor, Philokles of Egypt or Kleanthes of Corinth first practitioners, Arideikes of Corinth and Telephanes of Sikyon

a. no colour

b. first use of inner markings

c. added names to identify figures

4. Painting with colour-inventor, Ekphantos of Corinth

Plin. N.H. $x x x v 55-56$

Stages:

I. - - [no similar first stage mentioned] - -

2. Monochrome painters-Hygiainon, Deinias, Charmadas, and Eumaros of Athens

3. Linear drawing?-Eumaros of Athens

a. differentiated men from women (outline and reservation for female flesh)

b. imitated every sort of figure

[4. Boularchos-'art attained greatness-even perfection']

5. Kimon of Kleonai-katagrapha (profile drawing?)

various postures

attachment of limbs

prominence of veins

winding of drapery

6. Panainos-extensive use of colour

perfection of technique

portraits

It is now worth comparing Pliny's development of 'free' painting with the advances made in Corinthian and Attic vase painting: ${ }^{57}$

Stages:

I. [Nothing comparable to Pliny's stage I. ${ }^{58}$ ]

2. 'Monochrome'-Silhouette figures-Geometric and Subgeometric styles, eighth and seventh cent.

Black-figure-Protocorinthian, begins ca. $700 \mathrm{BC}$

3. Linear drawing outline-(Protoattic - work of the Analatos Painter, Protocorinthian-for faces of sphinxes ${ }^{59}$

55 Plin. N.H. xxxv I 52.

56 The names of the three clay workers mentioned by Pliny have been thought to be epithets rather than real names. There is, however, some recent archaeological evidence to suggest otherwise. A terracotta antefix was found at Camarina, Sicily signed by a certain Diopos, the same name as another of the three clayworkers accompanying Demaratos. For the antefix, see $A R$ 1976-7, 7I fig. 44, and other references, Croisille (n. 43) 262 n. 4 commentary on Plin. N.H. xxxv i 52 . The use of terracotta roof tiles was supposed to have been brought to Italy by Demaratos. Archaeological evidence for this, though scanty, supports a mid- seventh century date, see Ch. Williams, II, 'Demaratus and early Corinthian roofs', in $\Sigma \mathrm{TH} \wedge \mathrm{H}$, Tómos kis

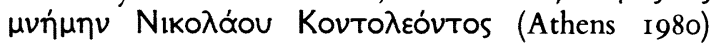
$345-50$.

57 Benson, (n. 3) 89 makes a similar comparison, but he places the beginning of polychrome vase painting earlier, in his Early Protocorinthian III style, see above n. II.

58 Silhouette figures, such as in Geometric vase painting, are not painted as described in this stage, i.e. outlining a shadow.

59 Robertson's second phase of outline drawing, $B S A$ xliii (1948) 58-9. 


\section{inner markings}

distinction between man and woman

(outline and reservation for female flesh)

labels for figures, Protocorinthian and Protoattic (examples begin in the second quarter of the seventh century)

4. Polychrome-Protocorinthian, Protoattic and other fabrics - mid-seventh century

5. Various postures, developed drapery drawing, detailed anatomical rendering - sixth century

6. 'Perfection of technique'? - red-figure, white ground, fifth century

It has often been noted how closely the two art forms, vase and 'free' painting must have progressed in the Archaic period. ${ }^{60}$ The skills of 'free' painting could easily be repeated on vase painting at least until the Classical age. It is, therefore, not only to be expected that the stages of development occur in the same order in both, but that the dates of these stages are closely similar in both 'free' and vase painting. As we can see from Plin. N.H. xxxv $55-56$ and the above summary of the development of Attic and Corinthian vase painting, Boularchos' painting seems to fit into Pliny's development at the stage of 'perfection' where colour was introduced, or chronologically about the mid-seventh century or later. ${ }^{61}$

Pliny's two passages coincide quite well for the second, third and fourth stages of development. Linear drawing is not mentioned in the second passage, but it can be assumed from what he says of the monochrome painter, Eumaros, that linear drawing was known. The obvious way to differentiate men from women in monochrome painting was to leave women's flesh reserved, in other words to outline the exposed parts of women's bodies. Evidence for this can be seen in vase painting by the first quarter of the seventh century. ${ }^{62}$ The stimulus for this, as for the art of linear drawing in general which began about the late eighth or early seventh century, may have come from oriental minor arts. ${ }^{63}$ Boularchos' painting follows after this, and is assumed by Pliny to be in colour if we may judge both from its relative position in the second passage compared with the first, and also from Pliny's mention of the art of painting reaching a level of 'greatness', 'even perfection' at this point. He uses these terms both of Boularchos' painting and stage four in his first passage when he talks of contemporary painting in Italy.

Just before the use of polychrome begins in Greek painting, Pliny says that names were added to paintings to identify the depicted figures. Evidence for this practice in vase painting points to the second quarter of the century. The Amphiaraos vase in Protocorinthian has been dated early in this quarter; ${ }^{64}$ the Menelas stand in Protoattic belongs to this quarter or the midseventh; ${ }^{65}$ and one of the early polychrome vases from Naxos, PLATE $\operatorname{IV}(a)$, has a figure of Aphrodite with her name written beside her. ${ }^{66}$ The archaeological evidence is quite clear. By

60 For example, Robertson (n. 22).

61 Pliny, N.H. xxxv 56 notes that the origin of painting (presumably in polychrome) was much earlier than the Boularchos painting and that monochrome painting was even earlier (aliquanto ante fuisse) than this. The development of linear drawing must be fitted in between.

62 E. Pfuhl, Malerei und Zeichnung der Griechen I (Munich 1923) 496 believed that colour was used to differentiate men from women, but Pliny here is talking about monochrome painters, so the differentiation should be by reservation or at most a lighter shade of the one colour. For examples of such reservation, especially for sphinxes' faces, see M. Robertson, $B S A$ xliii (1948) 50 fig. 35, and other references pp. 58-9; T. J. Dunbabin, ed., Perachora ii (Oxford I 962) 43-4 no. 255 with references to early Attic examples; perhaps also W. Kraiker, Aigina (Berlin I95 I) no. 267 pl. C (though Eriphyle's arm is not clearly discernible as being reserved in the published photograph, Kraiker, pl. I9).
The goddesses in the Judgment of Paris scene on the Chigi vase are drawn in outline with reservation, Johansen (n. 3) pl. 40.

${ }^{63}$ Robertson, $B S A$ xlvi (I95I) I 54 . For very early essays in outline drawing on Protocorinthian vases. see M. Robertson, $B S A$ xliii (1948) $55^{-9}$; T. J. Dunbabin$M$. Robertson, $B S A$ xlviii (I953) I73, A nos. I-7; B. F. Cook, British Museum Quarterly xxxvi (I972) I IO-I3 pls. $38-9 \mathrm{a}-\mathrm{b}$.

${ }^{64}$ Kraiker (n. 62) so no. 267 pls. C and I 9; Payne (n. 2) 98 n. 3 fig. 30 .

65 S. P. Morris, The Black and White style (New Haven I984) I 22 no. 9 pl. 7; J. M. Cook, $B S A$ xxxv (1934-5) I 89-90, 205 'stand from Aigina'.

66 The Chigi vase, from ca. 640, likewise has labelled figures in the Judgment of Paris scene. Johansen (n. 3) pl. 40. The script of the Chigi vase is non-Corinthian, possibly Syracusan (L. H. Jeffery, The local scripts of Archaic Greece [Oxford I96I] 264), though other scripts are also possible including Rhodian. 
comparison with seventh-century Greek pottery, Ekphantos' 'invention' of painting with colour should date a little before the mid-seventh century. Boularchos' painting should follow this.

Pliny (N.H. xxxv 55) tells us that the painting by Boularchos represented a battle (proelium) of the Magnesians, but in a second reference (N.H. vii I26) he notes that it depicted a destruction (excidium or exitium) of the Magnesians. It has long been noted that if the painting represented the famous destruction of the Magnesians ad Maeandrum known from Strabo (xiv 647) and dated $652 \mathrm{BC}$, then this painting could not have been bought by King Kandaules, who died ca. 685 BC. $^{67}$ The whole story should then, it was thought, be regarded as a fable.

The focus of the Boularchos anecdote is the great expense paid by the Lydian king for the tabula, no doubt a wooden plaque, which Pliny (N.H. vii i 26) adds was of no small size. The story was that the picture was bought for its weight in gold, and even if the price sounds suspiciously exaggerated, it must have been a very highly valued work.

Assuming, as we have, that vase painting gives an accurate reflection of the development of Greek 'free' painting, it is highly questionable whether any Greek painting produced in the reign of King Kandaules might be so highly prized as to become legendary with respect to its purchase price. ${ }^{68}$ This observation coupled with the reported theme of the painting, the battle or destruction of the Magnesians, makes Pliny's anecdote about Boularchos' painting impossible to accept as given. ${ }^{69}$ If, however, we suppose that Pliny mistakenly attached Kandaules' name to the story, perhaps because Kandaules was well known from Herodotus (i 7-13) for his foolish ways, or because of a possible association of Archilochos and Kandaules from Herodotus i I2, then there is hope of making sense of the anecdote.

It seems probable that it was indeed a Lydian king who purchased the painting, and not perhaps some Lydian aristocrat, also named Kandaules, living in the mid-seventh century or later. ${ }^{70}$ If we accept that the theme of the painting was the destruction of the Magnesians by the Treres, allies of the Kimmerians, ca. 652 BC (Str. xiv 647), the painting should then have been painted and purchased in the reign of Ardys, the son and successor of Gyges, since Gyges died at the hands of the Kimerians ca. $652 .{ }^{71}$ This, however, would place the painting just a short time after the introduction of the new polychrome style which in turn makes the purported cost of Boularchos' painting much more believable. A painting whose theme was directly relevant to the Lydian king and whose style was new and much more natural than all previous work, may well have commanded a very high price. Since Lydia's rise to wealth and power can only be traced as far back as Gyges, there is again no reason to think that it was any king earlier than Gyges who purchased the famed painting. The best explanation is that it was not Kandaules but the little known King Ardys who bought Boularchos' painting, if the story is true in any way.

67 C. O. Müller-F. G. Welcker, Ancient art and its remains (London I 852) 42; S. Reinach, REG viii (1895) 176-7.

${ }^{68}$ An observation first made by F. Jacoby, CQ xxxv (I94I) IO4 n. 4. Jacoby suggested instead Phoenician silver bowls as models for the Boularchos painting, but wherever Greek copying of Phoenician drawing can be identified, it is little better than any other Greek work. For Greek copying of Phoenician bowls, see B. Borell, Attisch geometrische Schalen (Mainz/Rhein 1978) $55^{-8} \mathrm{pl}$. 28; also Markoe (n. 40) 45-7 (vanquishing pharaoh type), 5I-2 (city-siege theme), I I 7-27 (Phoenician influence in Greece), esp. n. 156 for Phoenician influence on the Tiryns shield ca. 700-680 BC. For the date of this shield, see D. v. Bothmer, Amazons in Greek art (Oxford 1957) I-2.

${ }^{\circ} \mathrm{F}$. Jacoby, CQ xxxv (194I) I04-7 discusses all the known early wars associated either with Magnesia ad Maeandrum or Magnesia ad Sipylum. He favours the victory by Magnesia ad Sipylum allied with Lydia against the Amazons as the theme for Boularchos' painting ( $\mathrm{FGrH} 90 \mathrm{~F} 62$, J. G. Pedley, Ancient literary sources on Sardis [Cambridge Mass. I972] 20 no. 45). But Pliny makes no mention of the Lydians fighting on the side of the Magnesians which is surely a worthwhile detail if a Lydian king purchased Boularchos' painting. Even more important, Pliny refers to a destruction of the Magnesians, not a victory by them.

70 The name, Kandaules, was not uncommon in the region of Lydia. It is mentioned by Hipponax as a name or epithet of a Meonian deity, O. Masson, Les fragments du poète Hipponax (Paris I962) fr. 3 Pp. 31, I04-6; and see Hesychius, Test., 'Kandaules'. The father of a Carian sea captain also had the name, Hdt. vii 98 .

71 For dates and events, see H. Kaletsch, Historia vii (1958) 25-30. The destruction of Magnesia by the Treres is usually associated with the 652 campaign, though it may have occurred in the last campaign ca. 645 when Ardys was also beaten by the Treres and Lycians, and Sardis was briefly occupied. 
One final point emerges from this conclusion. If Kandaules is very doubtfully to be connected with the painting whose theme was a destruction of the Magnesians, then the connection between Kandaules and Archilochos, who mentions the evils of the Magnesians (Str. xiv 647), is equally doubtful. The arguments in favour of dates for Archilochos' career in the late eighth or early seventh century are weakened, and those in favour of dates about the midseventh century are strengthened. ${ }^{72}$

Gerald P. SChaus

Wilfrid Laurier University,

Waterloo, Ontario,

Canada, $\mathrm{N}_{2} \mathrm{~L}_{3} \mathrm{C}_{5}$

72 For the higher dates, see A. Blakeway, Greek see F. Jacoby, CQ xxxv (194I) 97-109, and note A. J. poetry and life (Oxford 1936) 34-55; for the lower dates, Graham, BSA lxxiii (1978) 6I-98, esp. p. 86. 